\title{
A Study of Non-English-Majored Graduates' Learning Burnout in a Local Comprehensive University in China
}

\author{
Yougen $\mathrm{Lou}^{1^{*}}$, Liansong $\mathrm{Wu}^{1}$, Honglian $\mathrm{Liu}^{2}$ \\ ${ }^{1}$ School of Foreign Studies, Yangtze University, Jingzhou, China \\ ${ }^{2}$ Jingzhou Experimental Middle School, Jingzhou, China \\ Email: *louyougen@163.com
}

Received 6 April 2016; accepted 22 May 2016; published 25 May 2016

Copyright (C 2016 by authors and Scientific Research Publishing Inc.

This work is licensed under the Creative Commons Attribution International License (CC BY). http://creativecommons.org/licenses/by/4.0/

(c) (i) Open Access

\begin{abstract}
Many non-English-majored graduates in colleges or universities complain about study stress. The purpose of the present study was to learn about non-English-majored graduates' actual burnout situation and to seek intervention; a questionnaire survey and written interviews were conducted in a local comprehensive university in China. 109 non-English-majored graduates were participants in this study. The results in this study showed that: 1) the participants experienced a low to medium level of learning burnout; 2) significant differences were found in the aspects of gender, grades and one subscale of inefficacy in majors. No significant differences were found two subscales (exhaustion and cynicism) in the aspects of majors; 3) meanwhile, the results of the interviews indicate four causes of learning burnout. Internal and external supports are categorized as the burnout reducers. As for intervention, non-English-majored graduates, the organization (colleges or universities) and society should work together to buffer the burnout syndrome.
\end{abstract}

\section{Keywords}

Non-English-Majored Graduates, Burnout, Local Comprehensive University

\section{Introduction}

The phenomenon of learning burnout is serious for non-English-majored graduate students' well-being. The term "burnout" was originated in Graham Greene's novel A Burnt-Out Case (1960), in which a desperate architect quits his job and escapes into the African jungle (cited in Maslach, 1976). Burnout is a psychological syn-

\footnotetext{
${ }^{*}$ Corresponding author.
}

How to cite this paper: Lou, Y. G., Wu, L. S., \& Liu, H. L. (2016). A Study of Non-English-Majored Graduates' Learning Burnout in a Local Comprehensive University in China. Creative Education, 7, 999-1006. 
drome which results from chronic stressors on the workplace (Maslach et al., 2001). Freudenberger (1974: p. 159) first used "burnout" to describe a social phenomenon, in which human service professionals are so exhausted that they can no longer perform their tasks effectively. A lot of research on burnout focused primarily on studying this concept in terms of how it related to occupational work (e.g., Maslach, Schaufeli, \& Leiter, 2001). In recent years, studies concerning burnout have extended towards researching non-occupational samples, such as students (e.g., Lin \& Huang, 2012; Schaufeli, Martinez, Marques-Pinto, Salanova, \& Bakker, 2002; Weckwerth \& Flynn, 2006). In addition to burnout among professionals, burnout among students has lately become an area of research—sometimes termed school burnout and academic burnout (Bilge et al., 2014). Researchers have found that stressors such as loneliness and burnout have become a common problem among students and something that they may encounter during their educational career (Arkar, Sari, \& Fidaner, 2004; Lin \& Huang, 2012; Ponzetti, 1990; Wiseman, Guttffeund, \& Lurie, 1995). The phenomenon of study-related stress, burnout and depression of higher education students has received a lot of attention in recent years (Meriläinen \& Kuittinen, 2014). However, there were few studies on non-English-majored graduates' learning burnout. This study was to investigate the non-English-majored graduates' learning burnout. Non-English-majored graduates in a local comprehensive university in China were chosen for this study. This study wanted to look for answers to the following questions:

1) Are these English teachers suffering from burnout?

2) If the answer is "Yes" to the first question, what is the degree of these students' burnout?

3) What factors may have caused the burnout syndrome?

4) What may be done to buffer?

\section{Literature Review}

\section{Students Learning Burnout}

Burnout is defined as Ban erosion of engagement that what started out as important, meaningful, and challenging work becomes unpleasant, unfulfilling, and meaningless (Maslach et al., 2001: p. 416). According to Maslach, Schaufeli, and Leiter (2001), burnout has three dimensions, namely emotional exhaustion, cynicism or depersonalization, and reduced personal accomplishment. Based on the three dimensions of burnout, Maslach defines student burnout as referring to feelings of exhaustion due to studying, reluctance to study or cynicism, and insufficiency as a student (Schaufeli et al., 2002). Learning burnout is based on the idea that "students become burned out in their learning process because of academic pressure, homework overload, or other individual psychological factors such as emotional exhaustion, negative attitudes, and the phenomenon of low personal accomplishment” (Lin \& Huang, 2012: p. 232). Thus, burnout is a negative emotional state characterized by feelings of exhaustion, cynicism, and inefficacy (Maslach et al., 2001). Along with further mental and physical health problems (Schaufeli et al., 2002), students experiencing learning burnout may also face factors such as: a low sense of achievement (a regression in feelings of competence and success in one's studies); depersonalization (a negative or detached response in social situations); emotional exhaustion (feeling emotionally drained); or, negative learning emotion (general negative perception of one’s learning experience) (Lin \& Huang, 2012).

A line of research has been done to investigate students' burnout in many countries.

Aypay (2011) investigated 691 elementary students’ burnout out of 10 schools in Eskisehir. Walburg (2015) reported 286 high school students' burnout in France and concluded burnout and especially the aspect of missing the purpose of and interest in one's school work increases the risk of cannabis consumption among high-school students. Bilge et al. (2014) investigated 605 high school students' levels of burnout in Ankara, Turkey and found that students with low self-efficacy beliefs had higher burnout levels. Çapri et al. (2013) reported the Study of Relations between Life Satisfaction, Burnout, Work Engagement and Hopelessness of High School Students. Dyrbye et al. (2009) investigated 3080 US medical students at five medical schools about factors related to students' burnout and concluded that a complex array of personal and professional factors influence student well-being, student satisfaction with specific characteristics of the learning environment appears to be a critical factor. Dyrbye et al. (2010) investigated 1321 US medical students and concluded that modifiable individual factors and learning climate characteristics including employment status, stress level and perceptions of the prioritising of student education by faculty members relate to medical students' vulnerability to burnout. Meriläinen \& Kuittinen (2014) reported the relation between Finnish university students' perceived level of study-related burnout, perceptions of the teaching-learning environment and perceived achievement motivation. 
Pavlakis \& Kaitelidou (2012) reported burnout syndrome in students of a distance learning program: the Open University of Cyprus experience and they investigated 142 distance learning students enrolled in the "Healthcare Management” course at the Open University of Cyprus.

In China, Jia (2009) examined the burnout level of 294 Hong Kong Chinese students enrolled in Bachelor and Master programs in architecture and its correlation with Confucian conformity values, the dominant societal cultural values in Confucian-Heritage-Cultures (CHC) society. And Gan (2007) compared the predictive value of locus of control and coping flexibility on two hundred and seventy-three Chinese university student burnout and, found that the construct of coping flexibility was composed of perceived controllability and strategy situation fit, which negatively predicted burnout and coping flexibility accounted for significant incremental variance beyond locus of control in predicting the three dimensions of burnout.

\section{Methods}

\subsection{Subjects}

This investigation was approved by Yangtze University. The subjects in this study were non-English-majored graduates from a local university, Yangtze University. From September of 2014 to January of 2015, 109 firstyear and second-year non-English-majored graduates in 5 classes from Yangtze University participated in this study. Among the 109 subjects, there were first-year non-English-majored graduates (Number $=54$ ), secondyear non-English-majored graduates (Number $=55$ ), females (Number $=63$ ), males (Number $=46$ ), liberal arts (Number $=53$ ) and sciences (Number $=56$ ), average age 23 with Chinese as the main language. Their majors were Chinese, economics, chemistry, agriculture, plant protection, finance, biological technology.

\subsection{Instruments}

In order to check the effects of burnout among non-English-majored graduates in Yangtze University, two types of instruments were used in this study: learning burnout questionnaires and interviews.

Learning Burnout. (Maslach Burnout Inventory-Student Survey; Schaufeli et al., 2002). The MBI-SS is a 15-item scale that assesses learning burnout/exhaustion among students. This scale measures 3 dimensions: Exhaustion (5 items), Cynicism (4 items), and Inefficacy (6 items). Exhaustion refers to the extent to which the student feels physically and/or mentally drained. Cynicism refers to the extent to which the student feels pessimistic towards their studies. Lastly, Inefficacy refers to the extent to which the student does not effectively complete their work.

The MBI-SS of statement relating to learning burnout with a 5-point scale ranging from "Almost Never (1)" to "Almost Always (5)" were used to score each item. A high scoreon Exhaustion , Cynicism and Inefficacy indicates a more intense experience of learning burnout. Schaufeli and colleagues (2002) reported instances of good internal consistency reliability across international samples (e.g., a $=0.86$ ). As well, Schaufeli and colleagues (2002) found support for the validity of the MBI-SS, as it accurately predicted burnout and was negatively correlated with the Utrecht School Engagement Scale (UWES-S). For the current study, Cronbach's alphas were 0.84 for Exhaustion, 0.71 for Cynicism, and 0.72 for Inefficacy, all of which were over 0.70, indicating that the instrument was valid for this study.

Interview. All 109 subjects participated in this study were filled out the written interview questionnaire about the following questions: 1) Do you have the feeling of being burned-out in learning? 2) If your answer to the first question is yes, what do you think may have led to your learning burnout? 3) How can you buffer your learning burnout according to your opinion? The second and third author interviewed all 109 subjects in this study. The interview was through QQ (a kind of on-line instant message service tool in China) and e-mail from October, 2014 to December 2014.

\subsection{Data-Collection}

The survey was conducted in September, 2015. The burnout questionnaires were distributed to all the 109 nonEnglish-majored graduates and 109 responses collected with complete data were used for the data analysis.

The interviews were conducted in November, 2015. The interview questions in written form, in Chinese, were sent through QQ (a kind of on-line instant message service tool in China) and e-mail to 109 colleagues, all 109 interview questionnaires were available. The time of data-collection of interviews of 109 colleagues were spent 
in four months.

\subsection{Data-Processing}

SPSS 17.0 was employed to process the collected data in this study. T-test was conducted to determine whether the learning burnout experienced by the participants differed significantly by gender, majors (Liberal Arts and Sciences) and grades. The interview responses were analyzed for themes

\section{Results}

\subsection{The Non-English-Majored Graduates (NEMGs) Learning Burnout Situation Indicated by the Survey}

\subsubsection{The General NEMGs' Learning Burnout Situation}

As shown in Table 1, the general non-English-majored graduates' learning burnout situation in the survey was shown that Exhaustion ( $M=2.89, S=1.08)$, Cynicism $(M=2.75, S=0.93)$, Inefficacy $(M=2.77, S=0.92)$. The average of means of all the three subscales of non-English-majored graduates' learning burnout was lower 3 points indicated that non-English-majored graduates suffered a low level to medium of learning burnout.

\subsubsection{The Differences of NEMGs' Learning Burnout between Genders}

As shown in Table 2, all the three subscales of learning burnout were significant differences between female non-English-majored graduates and male non-English-majored graduates, Exhaustion $(\mathrm{t}=-2.15, P=0.04)$, Суnicism $(\mathrm{t}=-3.81, P=0.00)$, Cynicism $(\mathrm{t}=-3.00, P=0.00)$. And male non-English-majored graduates' scores of meanat all the three subscales level of burnout were higher than female non-English-majored graduates' scores of meanat all the three subscales level of burnout.

\subsubsection{The Differences of NEMGs' Learning Burnout between Majors (Liberal Arts and Sciences)}

As shown in Table 3, two subscales of non-English-majored graduates' learning burnout were no significant differences between their majors (Liberal Arts and Sciences), Exhaustion ( $\mathrm{t}=-0.90, P=0.37)$, Cynicism $(\mathrm{t}=$ $1.91, P=0.06)$. However, there was the significant difference between Liberal Arts and Sciences at the inefficacy level of non-English-majored graduates' learning burnout.

\subsubsection{The Differences of NEMGs' Learning Burnout between Grades}

As shown in Table 4, all the three subscales of learning burnout were significant differences between grades, Exhaustion $(\mathrm{t}=-4.68, P=0.00)$, Cynicism $(\mathrm{t}=-4.13, P=0.00)$, Inefficacy $(\mathrm{t}=-2.57, P=0.02)$.

Table 1. The general NEMGs' learning burnout situation.

\begin{tabular}{cccc}
\hline Subscales of burnout & N & M & S \\
\hline Exhaustion & 109 & 2.89 & 1.08 \\
Cynicism & 109 & 2.75 & 0.93 \\
Inefficacy & 109 & $2 . .77$ & 0.92 \\
\hline
\end{tabular}

$\mathrm{N}$ for number; $\mathrm{M}$ for Mean; S for standard deviation.

Table 2. The differences of NEMGs' learning burnout between genders.

\begin{tabular}{|c|c|c|c|c|c|c|c|}
\hline \multirow{2}{*}{ Subscales of burnout } & \multirow{2}{*}{ Items } & \multicolumn{2}{|c|}{ Female (N = 63) } & \multicolumn{2}{|c|}{ Male $(\mathrm{N}=46)$} & \multicolumn{2}{|c|}{ T-test } \\
\hline & & M & $\mathrm{S}$ & M & $\mathrm{S}$ & $\mathrm{t}$ & $P$ \\
\hline Exhaustion & & 2.39 & 0.86 & 2.73. & 0.77 & -2.15 & $0.04^{*}$ \\
\hline Cynicism & & 2.25 & 0.79 & 2.89 & 1.04 & -3.82 & $0.00^{* *}$ \\
\hline Inefficacy & & 2.39 & 1.02 & 2.91 & 0.89 & -3.04 & $0.00^{* *}$ \\
\hline
\end{tabular}

N for number; M for Mean; S for standard deviation; ${ }^{* *} P<0.01,{ }^{*} P<0.05$. 
Table 3. The differences of NEMGs’ learning burnout between majors.

\begin{tabular}{|c|c|c|c|c|c|c|c|}
\hline \multirow[b]{2}{*}{ Subscales of burnout } & \multirow{2}{*}{ Items } & \multicolumn{2}{|c|}{ Liberal arts $(\mathrm{N}=53)$} & \multicolumn{2}{|c|}{ Sciences $(N=56)$} & \multicolumn{2}{|c|}{ T-test } \\
\hline & & M & $\mathrm{S}$ & M & $\mathrm{S}$ & $\mathrm{t}$ & $P$ \\
\hline Exhaustion & & 2.79 & 0.77 & 2.89 & 0.80 & -0.90 & 0.37 \\
\hline Cynicism & & 2.94 & 0.79 & 2.64 & 0.75 & 1.91 & 0.06 \\
\hline Inefficacy & & 2.94 & 0.93 & 2.54 & 0.85 & 2.31 & $0.03^{*}$ \\
\hline
\end{tabular}

$\mathrm{N}$ for number; $\mathrm{M}$ for Mean; $\mathrm{S}$ for standard deviation; ${ }^{*} \mathrm{P}<0.05$.

Table 4. The differences of NEMGs' learning burnout between grades.

\begin{tabular}{clccccccc}
\hline & Items & \multicolumn{2}{c}{ First year $(\mathrm{N}=54)$} & \multicolumn{2}{c}{ Second year $(\mathrm{N}=55)$} & \multicolumn{3}{c}{ T-test } \\
\cline { 2 - 8 } Subscales of burnout & $\mathrm{M}$ & $\mathrm{S}$ & $\mathrm{M}$ & $\mathrm{S}$ & $\mathrm{t}$ & $P$ \\
\hline Exhaustion & 2.33 & 0.80 & 2.95 & 0.78 & -4.68 & $0.00^{* *}$ \\
Cynicism & 2.24 & 0.80 & 2.89 & 0.83 & -4.13 & $0.00^{* *}$ \\
Inefficacy & 2.41 & 0.86 & 2.87 & 0.82 & -2.57 & $0.02^{*}$ \\
\hline
\end{tabular}

$\mathrm{N}$ for number; $\mathrm{M}$ for Mean; $\mathrm{S}$ for standard deviation; ${ }^{* *} \mathrm{P}<0.01,{ }^{*} \mathrm{P}<0.05$.

\subsection{The Causes of Non-English-Majored Graduates' Learning Burnout Indicated by Interviews}

The survey and the interviews suggested that many non-English-majored graduates in the local comprehensive university in this study were experiencing burnout, although their level of burnout may differ from persons to persons. What factors may have caused the burnout syndrome among the interviews' respondents?

The causes of non-English-majored graduates' learning burnout were categorized into four types of stressors: factors related to research assignment, job, major, and family.

Fifty respondents reported research assignment-related stressors. Thirty-five respondents said that they felt burnout because they had a lot of research assignment assigned by their supervisors to be completed and they had a lot of papers related to their research needed to be written. Eleven respondents said that they had to collect a lot of experimental data assigned by their supervisors as a part of research assignment. Four respondents said their research assignment were so boring.

Thirty respondents reported job-related stressors. All the thirty respondents said that they did not quit their job before they came here to be as graduates, so they had to balance between job and study in university, they had to complete the assignment from their jobs.

Fifteen respondents reported major-related stressors. Ten respondents said that their majors were not easy to find a job when they graduated as graduates. Five respondents said that they were lack of interest in their majors.

Fourteen respondents reported family-related stressors. Ten respondents said their parents were in the situation of poor health, but they did not give their parents enough help to improve their health. Four respondents said they came from families of poverty, they were old enough but they could not improve their families' income condition.

\subsection{The Supports to Buffer Non-English-Majored Graduates' Learning Burnout Indicated by Interviews}

Chang (2009) categorized the sources of burnout into three main factors, individual, organizational, and transactional. Individual factors are related to demographical data such as interest, age, gender, majors and grades. Organizational factors are related to characteristics of learning environment such as a library with good equipment, care for non-English-majored graduates from university or teachers and motivation of students' interests in learning or study. Finally, transactional factors refer to interaction of individual and organizational factors such as norms of student-teacher interaction.

The interviewees' suggestions for buffering burnout were categorized into three types, external, internal and transactional supports. External supports contained the university providing non-English-majored graduates 
chances to learn or study in a good environment and providing more scholarships for non-English-majored graduates who are excellent suffering family-poverty; family members help non-English-majored graduates reduce stressors from family. Internal supports include self-encouragement, being optimistic and improving their viewpoint about their academic development. Transactional supports contained the university provided supports to listen to non-English-majored graduates’ viewpoints on their burnout and their further development.

\section{Discussion}

The results in this study show that the phenomenon of non-English-majored graduates' learning burnout is a serious issue that needs to be emphasized before the effects of non-English-majored graduates' learning burnout lead to non-English-majored graduates, university and the country a lot of loss.

In this study, although non-English-majored graduates, in general, suffer a low to medium degree of learning burnout, university administrations should pay attention to non-English-majored graduates' learning burnout, because burned-out non-English-majored graduates tend to be irritable at home and in class, suffering from anxiety.

All the three subscales of learning burnout were significant differences between female non-English-majored graduates and male non-English-majored graduates and mean scores of male non-English-majored graduates' learning burnout were higher than that of female non-English-majored graduates, which means male nonEnglish-majored graduates suffer higher level of learning burnout than female non-English-majored graduates, because compared to female non-English-majored graduates, male non-English-majored graduates don't have good enough self-control.

Compared to non-English-majored graduates studying on Liberal arts, non-English-majored graduates studying Sciences who spend more time and energy in their experiments feel more exhausted, but they feel more personal efficacy in looking for a better job.

All the three subscales of learning burnout were significant differences between grades. First-year non-English-majored graduates who come into colleges or universities to further development feel excited, so they suffer a low level of learning burnout. However, second-year non-English-majored graduates who have to complete their experiments to write their academic thesis for master degree and some of second-year non-English-majored graduates need to look for jobs in their third academic year suffer higher level of learning burnout.

Solutions for non-English-majored graduates' learning burnout are improvement of university learning environment; rewarding ambition, commitment, motivation, and performance; providing more scholarships; donations from society. According to the findings of the interviews, what the non-English-majored graduates can do is to keep psychologically healthy by depending on internal as well as external supports. As non-Englishmajored graduates, they can learn lot of skills such as dancing, regular exercises to buffer the burnout. At the same time, all kinds of supports from college or university, society and family as the external supports to help non-English-majored graduates to buffer the learning burnout. For example, they can communicate with teachers or family members about their learning burnout.

\section{Limitation and Suggestions for Further Research}

Though the present study has provided a survey detailed description of the non-English-majored graduates' burnout, there are still some limitations of the study. Having the limitations in mind, suggestions for further research, therefore, can be put forward at the same time in order to achieve a lot thorough understanding of the non-English-majored graduates' burnout and buffering non-English-majored graduates' burnout.

Firstly, being time limitation (only a term) and other practical restrictions such as the subjects in the study consisted of only109 non-English-majored graduates' in one university need to be broadened in further research.

Secondly, the instruments used to investigate the non-English-majored graduates' burnout involve structured questionnaire and interviews. The study would be much better, if it were combined with other instruments such as observation, verbal report. More instruments should be used in investigation in further research.

Finally, participates in this study are the non-English-majored graduates' in a university. Results of other students' burnout such as undergraduates, we need further research.

Despite of the restraints of the study, it is hoped that it can offer some guidelines for further research on non-English-majored graduates' burnout. 


\section{Conclusion}

This study intended to examine the components and situation of learning burnout of non-English-majored graduates in a local comprehensive university in mainland China. 109 non-English-majored graduates' were as the participants in this study. The results in this study showed that: 1) the participants experienced a low to medium level of learning burnout; 2) significant differences were found in the aspects of gender, grades and one subscale of inefficacy in majors. No significant differences were found two subscales (exhaustion and cynicism) in the aspects of majors; 3) meanwhile, the results of the interviews indicate four causes of learning burnout. Internal and external supports are categorized as the burnout reducers. As for intervention, non-English-majored graduates, the organization (colleges or universities) and society should work together to buffer the burnout syndrome.

\section{References}

Arkar, H., Sari, O., \& Fidaner, H. (2004). Relationships between Quality of Life, Perceived Social Support, Social Network, and Loneliness in a Turkish Sample. Journal of Psychiatry, Neurology, and Behavioral Sciences, 42, 20-27.

Aypay, A. (2011). Elementary School Student Burnout Scale for Grades 6-8: A Study of Validity and Reliability. Educational Sciences: Theory and Practice, 11, 520-527.

Bilge, F., Dost, M. T., \& Çetin, B. (2014). Factors Affecting Burnout and School Engagement among High School Students: Study Habits, Selfefficacy Beliefs, and Academic Success. Educational Sciences: Theory and Practice, 14, 1721-1727.

Çapri, B., Gündüz, B., \& Akbay, S. E. (2013). The Study of Relations between Life Satisfaction, Burnout, Work Engagement and Hopelessness of High School Students. International Education Studies, 6, 35-46. http://dx.doi.org/10.5539/ies.v6n11p35

Chang, M. L. (2009). An Appraisal Perspective of Teacher Burnout: Examining the Emotional Work of Teachers. Educational Psychology Review, 21, 193-218. http://dx.doi.org/10.1007/s10648-009-9106-y

Dyrbye, L. N., Power, D. V., Massie, F. S., Eacker, A., Harper, W., Thomas, M. R., Szydlo, D. W., Sloan, J. A., \& Shanafelt, T. D. (2010). Factors Associated with Resilience to and Recovery from Burnout: A Prospective, Multi-Institutional Study of US Medical Students. Medical Education, 44, 1016-1026. http://dx.doi.org/10.1111/j.1365-2923.2010.03754.x

Dyrbye, L. N., Thomas, M. R., Harper, W., Massie Jr., F. S., Power, D. V., Eacker, A., Szydlo, D. W., Novotny, P. J., Sloan, J. A., \& Shanafelt, T. D. (2009). The Learning Environment and Medical Student Burnout: A Multicentre Study. Medical Education, 43, 274-282. http://dx.doi.org/10.1111/j.1365-2923.2008.03282.x

Freudenberger, H. J. (1974). Staff Burn-Out. Journal of Social Issues, 30, 159-165. http://dx.doi.org/10.1111/j.1540-4560.1974.tb00706.X

Gan, Y. Q., Shang, J. Y., \& Zhang, Y. L. (2007). Coping Flexibility and Locus of Control as Predictors of Burnout among Chinese College Students. Social Behavior and Personality, 35, 1087-1098. http://dx.doi.org/10.2224/sbp.2007.35.8.1087

Jia, Y. A., Rowlinson, S., Kvan, T., Lingard, H. C., \& Yip, B. (2009). Burnout among Hong Kong Chinese Architecture Students: The Paradoxical Effect of Confucian Conformity Values. Construction Management and Economics, 27, 287298. http://dx.doi.org/10.1080/01446190902736296

Lin, S. H., \& Huang, Y. C. (2012). Investigating the Relationships between Loneliness and Learning Burnout. Active Learning in Higher Education, 13, 231-243. http://dx.doi.org/10.1177/1469787412452983

Maslach, C. (1976). Burned-Out. Human Behavior, 5, 7-22.

Maslach, C., Schaufeli, W. B., \& Leiter, M. P. (2001). Job Burnout. Annual Review of Psychology, 52, 397-422. http://dx.doi.org/10.1146/annurev.psych.52.1.397

Meriläinen, M., \& Kuittinen, M. (2014). The Relation between Finnish University Students’ Perceived Level of StudyRelated Burnout, Perceptions of the Teaching-Learning Environment and Perceived Achievement Motivation. Pastoral Care in Education, 32, 186-196. http://dx.doi.org/10.1080/02643944.2014.893009

Pavlakis, A., \& Kaitelidou, D. (2012). Burnout Syndrome in Students of a Distance Learning Program: The Open University of Cyprus Experience. European Journal of Open, Distance and E-Learning, 1, 1-10.

Ponzetti, J. J. (1990). Loneliness among College Students. Family Relations: An Interdisciplinary Journal o f Applied Family Studies, 39, 336-340. http://dx.doi.org/10.2307/584881

Schaufeli, W. B., Martinez, I. M., Marques-Pinto, A., Salanova, M., \& Bakker, A. B. (2002). Burnout and Engagement in University Students: A Cross-National Study. Journal of Cross-Cultural Psychology, 33, 464-481.

http://dx.doi.org/10.1177/0022022102033005003

Walburg, V., Moncla, D., \& Mialhes, A. (2015). Burnout among High-School Students and Cannabis Use, Consumption 
Frequencies, Abuse and Dependence. Child Youth Care Forum, 44, 33-42. http://dx.doi.org/10.1007/s10566-014-9268-8 Weckwerth, A. C., \& Flynn, D. M. (2006). Effect of Sex on Perceived Support and Burnout in University Students. College Student Journal, 40, 237-249.

Wiseman, H., Guttfreund, D. G., \& Lurie, I. (1995). Gender Differences in Loneliness and Depression of University Students Seeking Counseling. British Journal of Guidance \& Counseling, 23, 231-243.

http://dx.doi.org/10.1080/03069889508253008 